\title{
Pemberdayaan Perempuan Melalui Pengelolaan Sampah Plastik di Kelurahan Air Tawar Barat Kota Padang

\author{
Herfina Lara Putri ${ }^{1}$, Syuraini ${ }^{1}$
}

${ }^{1}$ Jurusan Pendidikan Luar Sekolah, Fakultas Ilmu Pendidikan, Universitas Negeri Padang *e-mail: herfinaara14@gmail.com

(Diterima: 30 Meil 2020, direvisi: 3 Juli 2020, disetujui: 30 Juli 2020)

\begin{abstract}
Abstrak
Abstrak memuat uraian singkat mengenai tujuan penelitian, metode yang digunakan, dan hasil penelitian. Penekanan penulisan abstrak terutama pada hasil penelitian. Abstrak ditulis dalam bahasa Indonesia dan Bahasa Inggris. Jumlah kata dalam abstrak 100-150 kata. Jumlah kata kunci 3-5 kata/istilah. Kata kunci diperlukan untuk indekssasi. Pencarian judul penelitian dan abstraknya dipermudah dengan kata-kata kunci tersebut. Abstrak tidak boleh melebihi halaman pertama. Dan bagian PENDAHULUAN diawali dari halaman ke dua. Sangat dianjurkan untuk menulis artikel dengan cara mengedit template ini. Sangat dianjurkan untuk menulis artikel dengan cara mengedit template ini. Sangat dianjurkan untuk menulis artikel dengan cara mengedit template ini. Sangat dianjurkan untuk menulis artikel dengan cara mengedit template ini. Sangat dianjurkan untuk menulis artikel dengan cara mengedit template ini.
\end{abstract}

Kata Kunci: isi, format, artikel.

\begin{abstract}
An abstranct is a brief summary of a research article, thesis, review, conference proceeding or any-depth analysis of a particular subject or disipline, and is often used to help the reader quickly ascertain the paper purposes. When used, an abstract always appears at the beginning of a manuscript or typescript, acting as the point-of-entry for any given academic paper or patent application. Absatrcting and indexing services for various academic discipline are aimed at compiling a body of literature for that particular subject. Abstract length varies by discipline and publisher requirements. An abstranct is a brief summary of a research article, thesis, review, conference proceeding or any-depth analysis of a particular subject or disipline, and is often used to help the reader quickly ascertain the paper purposes. When used, an abstract always appears at the beginning of a manuscript or typescript, acting as the point-of-entry for any given academic paper or patent application.
\end{abstract}

Keywords: content, formatting, article. 


\section{PENDAHULUAN}

Pemberdayaan masyarakat ialah salah satu bentuk usaha yang dapat meningkatkan kesejahteraan pada masyarakat. Konsep pemberdayaan bertujuan untuk menjadikan sesuatu menjadi adil dan lebih efektif dalam seluruh lapisan aspek masyarakat[1]. Berbagai hal dapat dilakukan untuk memberdayakan masyarakat, mulai dari program perbaikan lingkungan tempat tinggal sampai kepada pengembangan usaha ekonomi dengan tujuan agar kesejahteraan hidup masyarakat dapat meningkat. Langkah yang dilakukan untuk pemberdayaan masyarakat tidak melulu membicarakan tentang tingkat kesejahteraan, melainkan seharusnya juga seyogyanya dengan memberikan pembelajaran dengan membicarakan nilai hidup seperti bagaimana cara hidup hemat, bekerja keras, terbuka, dan membicarakan ide-ide baru serta bagaimana untuk selalu berpikir maju kedepan.

Salah satu bentuk pemberdayaan masyarakat adalah melalui pemberdayaan terhadap kaum perempuan. Program pemberdayaan bagi perempuan ini berguna untuk menyeimbangkan keseteraan kaum laki-laki dan kaum perempuan pada lingkungan masyarakat, berbangsa dan bernegara. Latar belakang apapun yang ada pada lingkungan masyarakat harus bisa membebaskan dirinya akan diskriminasi dari perbedaan hak lakilaki dan hak perempuan.

Dalam kodratnya, seorang perempuan ialah sebagai ibu dalam sebuah rumah tangga, akan tetapi dalam bekerja seorang ibu juga memiliki sebuah hak. Walaupun bekerja itu merupakan kewajiban seorang laki-laki untuk mencari nafkah akan tetapi hal ini tidak menutup kemungkinan bagi kaum perempuan untuk aktif bekerja dalam rangka memenuhi kebutuhan rumah tangga. Tidak hanya dengan bekerja di kantoran akan tetapi bisa juga dilakukan di rumah. Seperti halnya yang dikerjakan oleh sekelompok perempuan di Kelurahan Air Tawar Barat, Kecamatan Padang Utara, Kota Padang, yang tergabung dalam Kelompok Usaha Bersama (KOPUSMA) "Mawar" melalui kelompok tersebut para perempuan diberdayakan melalui pemanfaatan sampah plastik. Kelompok ini berangotakan ibu-ibu rumah tangga, yang mana ibu-ibu rumah tangga ini hanya melakukan pekerjaan rumah saja, dan hanya bergantung pada uang penghasilan yang diberikan oleh suami mereka. Hal ini lah yang menimbulkan ketidak produktifan ibu-ibu rumah tangga karena cenderung memiliki waktu luang yang sangat banyak, dan juga masih banyaknya masyarakat yang berasal dari golongan ekonomi yang rendah. Dengan adanya kelompok ini diharapkan ibu-ibu dapat memanfaatkan waktu menjadi lebih produktif dan menghasilkan uang tambhan untuk keluarga mereka.

Lingkungan wilayah suatu masyarakat biasanya akan sesuai dengan kebiasaan masyarakat yang berada di lingkungan tersebut. Seperti contoh, bahwa lingkungan suatu lingkungan terlihat kumuh karena disebabkan oleh kebiasaan dari masyarakat sekitar yang tidak peduli dengan lingkungan, begitu sebaliknya. Sejatinya setiap masyarakat selalu mengharapkan lingkungan yang mereka tempati bersih, rapi, teratur dan bebas dari berbagai macam sampah. Keadaan lingkungan yang bersih serta terbebas dari segala jenis sampah tentu tidak akan tercipta begitu saja tanpa adanya usaha yang berarti dari masyarakat di lingkungan tersebut. Pola pikir masyarakat juga berpengaruh terhadap kebersihan sampah-sampah yang ada di lingkungan mereka, dimana masih 
banyak masyakat yang menanggap bahwa sampah merupakan benda yang tidak berguna.

Bermacam ragam jenis sampah yang dihasilkan oleh kegiatan manusia. Dimulai dari sampah kertas, hingga plastik. Akan tetapi diantara itu, sampah plastiklah yang paling sering ditemukan dan masih kesulitan dalam penangananya. Salah satu bentuk alternatif untuk dapat memanfaatkan kembali sampah plastik dengan cara mengolahnya kembali menjadi barang-barang layak pakai, atau menjadikannya sebagai sebuah kerajinan ataupun bentuk lainnya yang memiliki nilai jual. Beberapa hal yang sudah ditemukan, diperoleh bahwa pemerintah sebenarnya sudah menangani pengelolaan sampah dengan optimal. Akan tetapi yang menjadi persoalan ialah bahwa sebenarnya tingkat kesadaran masyarakat akan membuang sampah pada tempatnya tergolong sangat rendah. Hal ini dapat kita lihat dari masih banyaknya tumpukan sampah, sungai-sungai yang masih dijadikan tempat pembuangan sampah, serta timbulnya lingkungan yang tidak bersih diakibatkan oleh penumpukkan sampah.

Hal serupa mengenai kurangnya kesadaran masyarakat akan sampah plastik juga terjadi di Kelurahan Air Tawar Barat, Kecamatan Padang Utara, Kota Padang, sampah plastik yang ada masih banyak dibiarkan begitu saja tidak ditangani ataupun diolah sehingga menyebabkan lingkungan menjadi kumuh dan terlihat tidak sedap dipandang oleh mata. Selain itu banyaknya sampah akan menimbulkan permasalahan kesehatan terhadap masyarakat yang disebabkan oleh bakteri yang berkembangbiak dari sampahsampah tersebut, hingga bisa menimbulkan berbagai penyakit. Untuk mengatasi permasalahan tersebut tidaklah mudah, perlu adanya penanaman kesadaran kepada masyarakat untuk mau mengolah sampah plastik yang ada tersebut. Serta juga diperlukan individu yang mempunyai waktu yang cukup luang untuk mengolah sampah-sampah plastik tersebut, karena dalam pengolahan sampah plastik menjadi suatu kerajinan membutuhkan ketelatenan, keuletan, dan waktu yang ekstra dari pengolah. Salah satu cara untuk dapat terlaksananya pengolahan sampah menjadi barang yang mempunyai nilai jual yaitu dengan melakukan pemberdayaan terhadap masyarakat yang memiliki waktu luang dan berkeinginan tinggi dalam mengolah sampah khususnya kepada kaum perempuan yang ada di lingkungan tersebut.

Hal inilah yang peneliti temui pada kaum perempuan yang ada di Kelurahan Air Tawar Barat, Kecamatan Padang Utara, Kota Padang. Dari hasil observasi dan pengamatan peneliti di lapangan, ibu-ibu di kelurahan ini tidak ada rasa malu ataupun gengsi untuk sekedar memungut dan memilah sampah-sampah plastik yang ada di sekitar lingkungannya. Sampah-sampah plastik ini mereka kumpulkan lalu diolah menjadi berbagai benruk barang dan kerajinan tangan yang memiliki nilai jual serta manfaat. Untuk mengolah sampah-sampah plastik ini mereka berkumpul dalam suatu kelompok perempuan yang di beri nama Kelompok Usaha Masyarakat (KOPUSMA) "Mawar".

Kelompok Usaha Masyarakat (KOPUSMA) "Mawar” yang ada di Kelurahan Air Tawar Barat, Kecamatan Padang Utara, Kota Padang, merupakan salah kelompok pemberdayaan perempuan yang bergerak pada bidang pengelolaan sampah plastik yang ada di kelurahan tersebut. Kelompok ini berdiri sejak dua tahun yang lalu yaitu tahun 2017 yang memiliki komitmen tinggi untuk memberdayakan para perempuan 
disekitarnya sekaligus mengurangi limbah sampah plastik dilikungannya. Kelompok Usaha Mayarakat "Mawar" ini beranggotakan sebanyak 22 orang.

Anggota dari kopusma mawar ini adalah ibu rumah tangga, yang berada di Kelurahan Air Tawar Barat, yang kegiatan seharinya hanya mengurus rumah tangga dan lebih banyak mempunyai waktu luang yang banyak, ditambah lagi dengan belum adanya kegiatan positif yang dilakukan oleh ibu-ibu tersebut. Mayoritas kehidupan masyarakat yang berada di lingkungan kopusma mawar ini tergolong berekonomi rendah, dikarenakan rata-rata masyarakat bekerja sebagai nelayan. Untuk mengisi waktu luang yang dimiliki para ibu-ibu tersebut mengolah sampah plastik menjadi aneka kerajinan tangan dengan mempunyai nilai jual. Kegiatan yang dilakukan mencakup halhal mulai dari memungut sampah plastik, lalu mengumpulkannya, mengelompokkannya, memilah dan memilih jenis plastik yang akan didaur ulang, dan mengolahnya menjadi suatu barang. Dengan dilaksanakannya kegiatan pengolahan sampah ini diharapkan nantinya dapat meningkatkan perekonomi keluarga.

Berdasarkan hasil wawancara dengan ibu I (31 oktober 2019) yang merupakan salah seorang anggota kelompok, beliau mengatakan minat dirinya untuk bergabung diawali karena rasa keingintahuannya yang tinggi perihal pengelolaan sampah yang dilakukan oleh ketua kelompok. Beliau juga menyatakan kelompok ini berdiri awalnya dari orang per orangan, karena tingkat keingintahuan tadi yang tinggi sehingga banyak ibu-ibu yang berminat membuat kerajinan tangan melalui pengelolaan sampah tersebut. Sejak itulah mereka memutuskan untuk mendirikan kelompok pemberdayaan perempuan yang diberi nama KOPUSMA “Mawar" ini.

Peneliti sebelumnya juga melakukan wawancara dengan ibu S yang merupakan ketua kelompok usaha masyarakat "mawar", sampah-sampah plastik yang ada dipungut langsung oleh para ibu-ibu tersebut, mulai dari memanfaatkan sampah-sampah plastik pemakaian limbah rumah tangga mereka, lalu ada juga yang sengaja di pungut oleh ibu ibu di sekitar lingkungannya tanpa ada rasa malu karena adanya keinginan mereka untuk mengolahnya. Ibu S mengatakan awalnya ibu-ibu ini mengelola atau membuat kerajinan tangan melalui sampah ini untuk koleksi atau pemakaian pribadi saja, lalu karena ada nya wadah untuk menjual maka semangat ibu-ibu untuk mengelola semakin tinggi. Jadi semakin banyak juga kerajinan tangan yang mereka buat. Dalam hal membuat kerajinan atau mengelola sampah plastik ini diajari langsung oleh ibu S selaku ketua dan pengelola kelompok usaha masyarakat ini. Hasil dari pengelolaan tersebut dijual melalui pameran-pameran yang ada di kota padang, mulai dari pameran di tingkat kecamatan bahkan kota. Hasil pengelolaan itu juga dijual ke dosen dosen yang ada di UNP yang dipasarkan oleh tetangga ibu S, dapat dipasarkan di kalangan dosen ini karena Kelurahan Air Tawar Barat ini dekat dengan lingkungan kampus yaitu kampus Universitas Negeri Padang.

Usaha yang dilakukan oleh ibu-ibu yang tergabung di KOPUSMA ini tidak hanya sekedar dalam hal memungut, memilah, dan mengelola saja, mereka memiliki antusias serta semangat yang tinggi untuk menjual hasil kerjinan dari pengelolaan sampah yang mereka lakukan.

Berbagai jenis sampah plastik yang bisa dimanfaatkan dan diolah oleh ibu-ibu menjadi bahan kerajinan ialah sampah plastik kemasan minuman, kemasan makanan, 
permen, detergen, dan sampah plastik lainnya. Semua sampah-sampah yang sudah dikumpulkan ini pada nantinya akan dipilah dan dipilih serta dilakukan pengkategorisasian yang didasarkan kepada jenis plastik hingga pada warna sampah plastik tersebut. Setelah dilakukan tindakan tersebut, kemudian sampah tersebut diolah menjadi berbagai jenis dan bentuk bahan kerajinan tangan seperti tikar, pouch, tas, dan lain-lainnya yang berguna dan memiliki nilai jual.

Dalam melakukan kegiatan, Kopusma juga mengikutsertakan seluruh komponen warga masyarakat yang berada di sekitar lingkungan Kopusma ataupun yang berada di sekitar Kelurahan Air Tawar Barat untuk juga ikut mengumpulkan serta mengolah berbagai sampah plastik yang ada.Selain itu, Kopusma aktif mengadakan pelatihan mengenai pengelolaan sampah kepada masyarakat.Tujuan diadakannya kegiatan tersebut ialah untuk menciptakan kondisi lingkungan yang bersih, menjadikan masyarakat yang mandiri, dan untuk menciptakan peningkatan kesejahteraan masyarakat. Hal ini dikarenakan sebagian besar masyarakat kurang memiliki kreatifitas dan memiliki rasa cinta lingkungan yang rendah.

Berdasarkan pada fenomena yang dikemukakan, maka penulis memiliki keinginan untuk melakukan sebuah penelitian dengan judul pemberdayaan perempuan melalui pengolahan sampah plastik di Kelurahan Air Tawar Barat, Kecamatan Padang Utara, Kota Padang.

\section{METODE}

Jenis penelitian ini adalah penelitian kualitatif, menggunakan pendekatan fenomenologi. Metodologi kualitatif merupakan prosedur penelitian yang menghasilkan data deskriptif berupa kata-kata yang tertulis maupun yang diucapkan dari lisan orangorang dan perilaku yang diamati [2]. Pendekatan fenomenologi bertujuan untuk menginterprestasikan tindakan sosial kita dan orang lain sebagai sebuah yang bermakna serta dapat merekontruksi kembali turunan makna dari tindakan yang bermakna pada komunikasi intersubjektif individu dalam dunia kehidupan social [3]. Variabel yang akan diteliti yaitu bagaimana motivasi anggota kelompok usaha bersama (KOPUSMA) "Mawar" dalam mengikuti pemberdayaan perempuan melalui pengelolaan sampah plastik yang terdiri dari aspek motivasi intrinsik dan motivasi ekstrinsik.

Sumber data dalam penelitian ini adalah subjek penelitian yaitu anggota kelompok usaha bersama "mawar" dan informan penelitian yaitu pengurus atau pengelola dari kelompok usaha bersama "mawar". Teknik pengumpulan data mengunakan observasi, wawancara dan dokumentasi. Sedangkan untuk menarik kesimpulan berdasarkan teknis analisis data yang diungkapkan [4] yaitu reduksi data, penyajian data. Data yang sudah dianalisis kemudian diuji keabsahannya dengan triangulasi sumber, teknik, dan waktu.

\section{HASIL DAN PEMBAHASAN}

Berdasarkan masalah yang dikemukakan pada pendahuluan, penelitian ini bertujuan untuk mendeskripsikan bagaimana motivasi anggota kelompok usaha bersama (KOPUSMA) "Mawar" dalam mengikuti pemberdayaan perempuan melalui pengelolaan sampah plastik yang terdiri dari beberapa aspek yaitu 


\section{Gambaran Motivasi Instrinsik Anggota dalam mengikuti Pemberdayaan Perempuan melalui pengelolaan sampah plastik di Kelurahan Air Tawar Barat}

Gambaran motivasi para anggota untuk bergabung dan mengikuti kegiatan pemberdayaan melalui pengelolaan sampah plastik dilihat dari motivasi intrinsik anggota yaitu peneliti melakukan wawancara dengan anggota, dan pengurus kelompok usaha bersama "Mawar". Dari wawancara yang dilakukan peneliti menyimpulkan bahwa salah satu motivasi mereka dalam bergabung yaitu: Pertama karena adanya rasa yang timbul dari dalam diri mereka sendiri. Adanya rasa ingin belajar dan mengetahui hal hal baru yang bermanfaat bagi diri mereka sendiri serta bermanfaat untuk lingkungan sekitar mereka. Dorongan yang datang dari dalam diri mereka sendiri ketika melihat orang lain dapat melaksanakan sesuatu yang bermanfaat lalu mengapa mereka tidak bisa, maka dari itu timbulah motivasi dari diri sendiri untuk bergabung di kelompok usaha bersama "Mawar".

Kedua yaitu ingin membersihkan lingkungan dari sampah plastik. Para anggota kelompok memiliki kepekaan serta kepedulian yang sangat tinggi terhadap lingkungan tempat tinggal mereka. Ini dibuktikan dari pernyataan mereka yang mereka sampaikan, melalui pengelolaan sampah plastik ini mereka bisa mendaur ulang kembali sampahsampah plastik yang ada menjadi suatu hal yang bermanfaat dan bernilai jual, hal ini lah yang menjadi motivasi anggota untuk bergabung di Kelompok Usaha Bersama "Mawar".

Hal ini sesuai dengan pendapat yang disampaikan oleh [5] motivasi instrinsik merupakan motif-motif yang menjadi aktif atau fungsinya tidak membutuhkan rangsangan dari luar, sebab pada diri setiap individu sudah ada rangsangan untuk berbuat sesuatu. Namun, motivasi intrinsik tidak berarti bahwa seseorang tidak akan mencari imbalan. Ini hanya berarti bahwa imbalan eksternal semacam itu tidak cukup untuk membuat seseorang tetap termotivasi. Seorang warga belajar yang termotivasi secara intrinsik, misalnya, mungkin ingin mendapatkan nilai bagus pada sebuah tugas, tetapi jika tugas itu tidak menarik minat warga belajar itu, kemungkinan nilai yang bagus tidak cukup untuk mempertahankan motivasi warga belajar itu untuk melakukan segala upaya dalam proyek tersebut [6]. Memaksimalkan produktivitas di tempat kerja adalah prioritas utama untuk semua organisasi bisnis, tetapi terlalu sering fokus terbatas pada imbalan manfaat nyata seperti gaji, komisi, dan bonus.

Motivasi intrinsik ialah kemauan yang ada dalam diri seseorang untuk berbuat mengerjakan sesuatu yang dipengaruhi oleh aspek-aspek yang bersumber dari dalam dirinya dan tanpa adanya pengaruh oleh orang lain untuk mengerjakan sesuatu [7]. Motivasi intrinsik berkaitan dengan motivasi yang datang dari dalam individu daripada dari imbalan eksternal atau luar, seperti uang atau nilai. Motivasi berasal dari kesenangan yang didapat seseorang dari tugas itu sendiri atau dari rasa kepuasan dalam menyelesaikan atau bahkan bekerja pada sebuah tugas.

Dalam Motivasi Intrinsik di Tempat Kerja, mengeksplorasi kekuatan penghargaan intrinsik, imbalan psikologis yang didapat pekerja dari pekerjaan itu sendiri [8]. Perusahaan yang memanfaatkan penghargaan intrinsik dapat menciptakan lingkungan yang lebih terlibat, mengatur diri sendiri, dan berkomitmen untuk karyawan mereka. Berbicara kepada pekerja dan pemimpin tim, Motivasi Intrinsik di Tempat Kerja 
menggambarkan empat motivasi intrinsik yang dibutuhkan untuk meningkatkan manajemen diri pekerja: rasa pilihan, rasa kebermaknaan, rasa kompetensi, dan rasa kemajuan.

\section{Gambaran Motivasi EkstrinsikAnggota dalam mengikuti Pemberdayaan Perempuan melalui pengelolaan sampah plastik di Kelurahan Air Tawar Barat}

Gambaran motivasi para anggota untuk bergabung dan mengikuti kegiatan pemberdayaan melalui pengelolaan sampah plastik dilihat dari motivasi ekstrinsik anggota yaitu peneliti melakukan wawancara dengan anggota, dan pengurus kelompok usaha bersama "Mawar". Dari wawancara yang dilakukan peneliti menyimpulkan bahwa salah satu motivasi mereka dalam bergabung yaitu: Pertama yaitu adanya dorongan dari keluarga. Para anggota mendapatkan dukungan yang besar dari anggota keluarga untuk bergabung di kelompok usaha bersama "mawar" ini, dengan demikian para anggota memiliki motivasi yang lebih besar lagi dalam mengikuti pemberdayaan yang diberika di dalam kelompok untuk mendaur ulang sampah-sampah plastik yang nantinya akan dijadikan barang-barang yang bermanfaat dan memiliki nilai jual tinggi.

Kedua yaitu ingin menambah penghasilan. keikutsertaan para anggota bergabung di kelompok usaha bersama "mawar" di dorong dengan adanya keinginan dari luar diri yaitu untuk menambah penghasilan tambahan dari hasil penjualan pengelolaan sampah menjadi kerajinan. Anggota juga di dorong rasa ingin menjadikan pengelolaan sampah tersebut menjadi usaha sampingan, melalui kerajinan-kerajinan yang mereka buat, mereka bisa memasarkan nya dan mendapatkan uang tambahan.

Motivasi ekstrinsik ialah dorongan-dorongan yang muncul pada diri seseorang yang banyak dipengaruhi oleh hal-hal yang bersumber dari luar dirinya untuk dapat berbuat atau mengerjakan sesuatu hal dengan penuh semangat dan antuasian dalam mengapai keinginan yang sudah ditentukan [9]. Motivasi ekstrinsik menurut [10] diartikan sebagai suatu motif yang aktif dan juga berfungsi apabila dipengaruhi oleh rangsangan dari luar [10]. Kemudian [11] menyatakan motivasi ekstrinsik itu sebagai aspek yang berada di luar pengetahuan. Maksudnya ialah aspek tersebut tidak bersumber dari dalam dirinya sendiri.

Berdasarkan kepada pendapat yang sudah diuraikan tersebut, kesimpulan yang dapat diambil ialah motivasi ekstrinsik merupakan segala aspek yang bersumber dari luar diri individu yang memungkinkan dirinya untuk dapat terdorong mengerjakan sesuatu hal guna untuk menggapai tujuan yang sudah direncanakan.Motivasi ekstrinsik sebahagian besar cocok digunakan untuk mempengaruhi seseorang dalam mengerjakan sesuatu. Akan tetapi jenis ini juga tidak cocok apabila digunakan pada situasi tertentu.

Berdasarkan hasil temuan peneliti di lapangan motivasi ekstrinsik yang ada pada anggota kelompok usaha bersama "mawar" sangat tinggi, hal ini dibuktikan oleh adanya dorongan dari keluarga dan orang-orang sekitar, dukungan inilah yang memicu semangat para anggoa dalam mengikuti setiap kegoatan yang dilaksanakan di kelompok usaha bersama "mawar" ini.

Tidak hanya dorongan dan dukungan yang diberikan oleh keluarga, faktor atau dorongan lain yang memicu motivasi dari para peserta yaitu adanya peluang untuk membuka usaha dari pengelolaan sampah ini. Hal ini yang membuat para anggota menjadi semakin tekun dalam mengolah limbah sampah plastik menjadi kerajinan yang 
memiliki nilai jual, karena adanya harapan yang menguntungkun untuk kebaikan kehidupam para anggota kelompok tersebut.

Jadi dapat disimpulkan, gambaran motivasi anggota kelompok usaha bersama "mawar" dalam mengikuti program pengelolaan sampah dilihat dari sub fokus Motivasi Instrinsik dan Motivasi Ekstrinsik. Dari subyek yaitu para anggota kelompok usaha bersama "mawar" yang telah diteliti, rata-rata mereka mempunyai jawaban yang tepat untuk setiap pertanyaan dari masing-masing indikator keuntungan yang diajukan oleh peneliti.

\section{KESIMPULAN}

Berdasarkan uraian dari hasil penelitian dan pembahasan yang telah dilakukan, maka peneliti dapat menarik kesimpulan bahwa: Pertama gambaran motivasi instrinsik anggota kelompok usaha bersama "mawar" sudah tinggi, Hal ini dilihat dari keinginan para anggota untuk belajar dalam hal pengelolaan sampah plastik yang tidak bernilai guna menjadi suatu kerajinan atau barang yang memiliki nilai guna serta adanya dorongan untuk memanfaatkan waktu luang dengan mengisinya melalui kegiatan yang lebih produktif dengan cara mengolah sampah plastik menjadi kerajinan tangan yang bernanfaat seperti tas, dompet, dan taplak meja. Kedua gambaran motivasi ekstrinsik anggota Kelompok Usaha Bersama "Mawar" sangat baik, mereka menjadi lebih termotivasi karena adanya dorongan dan semangat dari anggota keluarga, kemudian adanya dorongan untuk membantu mencari penghasilan tambahan keluarga, yang mana pada umumnya para anggota hanya bekerja sebagai ibu tumah tangga yang tidak memiliki penghasilan, dengan mengikuti program ini para anggota dapat menambah perekonomian keluaga dan tidak hanya bergantung kepada penghasilan suami.

Sedangkan saran penelitian penelitian yaitu: Pertama bagi pengelola kelompok usaha bersama "mawar" yang melaksanakan program pemberdayaan perempuan melalui pengelolaan sampah plastik. Semoga pengelola dapat terus mengembangkan dan meningkatkan program pengelolaan sampah plastik ini menjadi lebih baik. tujuannya agar semakin banyak perempuan yang dapat diberdayakan melalui program ini, dan para anggota yang sudah bergabung menjadi pribadi yang lebih mandiri dan produktif. Kedua bagi pembaca hendak bisa dijadikan sebagai bahan referensi dan inovasi dalam bentuk pemberdayaan atau pengelolaan yang positif lainnya. Ketiga bagi masyarakat diharapkan penelitian in dapat memberikan pemahaman dan motivasi kepada masyarakat tentang pentingnya pengelolaan sampah di lingkungan agar sampah menjadi bermanfaat.

\section{REFERENSI}

[1] Adiyoso, W. (2009). Menggugat Perencanaan Partisipatif dalam Pemberdayaan Masyarakat. Surabaya: ITS Press.

[2] Moleong, L. (2013). Metodologi Penelitian Kualitatif. Bandung: PT. Remaja Rosdakarya.

[3] Sugiyono. (2017). Metode Penelitian Kuantitatif, Kulaitatif, dan R\&B. Bandung: Alfabeta. 
[4] Basrowi, \& Suwandi. (2008). Memahami Penelitian Kualitatif. jakarta: Rineka Cipta.

[5] Djamarah, S. B. (2012). Psikologi Belajar. Jakarta: Rineka Cipta.

[6] Safitri, V. \& S. (2019). Gambaran Motivasi Warga Belajar Pelatihan Keterampilan Menyulam Selendang Koto Gadang di PKBM Anarvani Padang. JFACE: Journal of Family, Adult, and Early Childhood Education, 3(1), 442-448.

Retrieved from http://ejournal.aksararentakasiar.com/index.php/jface/article/view/59

[7] Sesti, J. \& S. (2018). Gambaran Motivasi Warga Belajar Mengikuti Pelatihan Menjahit di PKBM Nurul Hidayah Kecamatan Kamang Magek Kabupaten Agam. Spektrum: Jurnal Pendidikan Luar Sekolah, 4(1), 449-455. Retrieved from http://ejournal.unp.ac.id/index.php/pnfi/article/view/101743

[8] Lickona, T. (2013). Mendidik untuk Membentuk Karakter. Jakarta: Bumi Aksara.

[9] Amelia, Dian Mitri, Elvi Maulida Putri, Hayu Irma, Hijatul Nadia, S. (2020). Hubungan Motivasi Belajar terhadap Metode Mengajar Guru Bahasa Indonesia Paket C di PKBM Farilla Ilmi. Jurnal Halaqah, 2(1), 45-53. Retrieved from http://ejournal.pamaaksara.org/index.php/hal/article/view/90

[10] Sardiman. (2011). Interaksi dan Motivasi Belajar Mengajar. Jakarta: Rajawali Press.

[11] Purwanto, N. (2011). Psikologi Pendidikan. Bandung: Remaja Rosdakarya. 
Halaman ini sengaja dikosongkan 